\section{Public perception of and engagement with emerging low-carbon energy technologies: A literature review}

Tarla Rai Peterson, Department of Communication, University of Texas at El Paso, El Paso, TX 79968

Jennie C. Stephens, Rubenstein School of Environmental \& Natural Resources, University of Vermont, Burlington, VT 05405

Elizabeth J. Wilson, Hubert H. Humphrey School of Public Affairs, University of Minnesota, Minneapolis, MN 55455

Address all correspondence to Elizabeth J. Wilson at ewilson@umn.edu

All authors contributed equally to this paper.

(Received 13 June 2015; accepted 31 July 2015)

\title{
ABSTRACT
}

Iransitioning to low-carbon energy systems depends on fundamental changes in technologies, policies, and institutions. In Western democracies, public perceptions and engagement with energy have encouraged innovation while also slowing deployment of low-carbon energy technologies (LCETs).

Transitioning to low-carbon energy systems requires re-engineering technologies and changing the ways people interact with energy. This shift involves both technological and social changes including modifications in policies and institutional configurations. In Western democracies, public perceptions and engagement with energy have encouraged innovation while also slowing deployment of low-carbon energy technologies (LCETs). To aid understanding of how energy systems are evolving toward lower-carbon technologies in Western democracies, this study reviews the literature on public perception of and engagement with emerging LCETs. Focusing primarily on electricity generating technologies, we explore how multiple factors related to place and process shape public perceptions of and engagement with LCETs, thereby influencing their development and deployment. This study first reviews literature related to how place and process influence emerging LCETs and then provides a comparative example of differential development of wind energy in Texas and Massachusetts (USA) to demonstrate how place and process may interact to influence the patterns of LCET deployment.

Keywords: education; environment; society; economics

\section{DISGUSSION POINTS}

- In Western democracies, the policy and institutional changes required to support commercial scale deployment of low-carbon energy technologies (LCETs) require public support.

- Careful examination of both place (where the project is located) and process (how the public engages with development and siting) provides opportunities for understanding the complex social contexts shaping future energy systems.

\section{Introduction}

"Where you stand depends on where you sit,"

"Miles Law" from Rufus Miles, Truman era Civil Servant ${ }^{1}$

Transitioning to low-carbon energy systems depends on fundamental changes in technologies, policies, and institutions. ${ }^{2,3}$
In Western democracies, policy and institutional changes require support from both individuals and communities. Public perceptions of and engagement with emerging LCETs are influenced by many factors including the local and regional contexts and the institutional processes that guide interactions among people and energy. ${ }^{4}$ Recognizing how critical place and process are in shaping perceptions and engagement, we have structured this review to first explore how place, including spatial, social and historical contexts, influences perceptions; and then to explore how formal and informal processes influence people's engagement with energy systems.

Many researchers have surveyed, interviewed, and studied people to understand general perceptions and preferences about energy technologies either individually or in comparison with others. ${ }^{5-17}$ This research demonstrates that individuals usually express positive perceptions toward LCETs, especially renewable energy technologies such as solar and wind. ${ }^{7,18}$ Less positive reactions have been documented regarding perceptions 
of biomass ${ }^{19-21}$ and low-carbon fossil fuel technology such as natural gas, technologies to enable control of fossil fuel emissions such as, carbon capture and storage (CCS) and nuclear energy. ${ }^{11,22-26}$ For example, a 2008 paper on public perceptions of energy technologies in the U.K. found over $75 \%$ of respondents ranked their impressions of sun/solar power, wind power, and hydroelectric power as very or mainly favorable. The percentage of respondents that had favorable views of other energy technologies was considerably lower with natural gas at $55 \%$, biomass at $54 \%$, oil at $39 \%$, coal at $38 \%$, and nuclear power at $36 \%$ favorable. ${ }^{27}$ Studies on public opinion in the United States and Europe show remarkably constant levels of support over time for wind, solar, and other renewable technologies. ${ }^{12,27-29}$

Other research has demonstrated that the public generally believes energy is an important issue. Polling data in the United States between 1979 and 2006 show that the percentage of respondents who believed the energy situation was a very or fairly serious issue ranged from a low of $72 \%$ to a high of $92 \%$ of surveyed respondents. These polls also found high levels of public support for policies to support energy efficiency, research on renewable energy technologies and commercial incentives to encourage development of wind and solar. ${ }^{29}$

This review moves beyond research about general public perceptions of energy technologies to research that focuses on public perceptions of and engagement with deployment of LCETs. This focus on deployment highlights our interest in moving from theories of technology diffusion to the practice of implementation. ${ }^{30}$ It is only when LCET projects are proposed and sited in specific locations that broad public engagement becomes concrete. Public perceptions are heightened and opinions are solidified through processes of engagement. Without specific projects and the detailed visual images and other sensory experiences associated with actual projects, energy technology development remains abstract for most members of the public. Once siting a project becomes a possibility, however, people become interested. At this point, previously ignored technologies or assemblages of technologies develop social significance. Another justification for the focus on deployment relates to our belief that responding and adapting to a changing climate requires a fundamental shift in how energy is produced and consumed. ${ }^{31}$ In Western democracies, citizen deliberations and public participation will play a critical role in shaping the future energy system and influencing the dynamics of energy system evolution. We see citizen participation and engagement as a critical component in the co-creation of future energy systems which must integrate and reflect larger societal values if they are to be built and sustained at the scale necessary to respond to a changing global climate.

This study first reviews literature related to how place and process influence emerging LCETs. We concentrate primarily on research relating to electricity generating LCETs and on research that connects with specific projects. The review is divided into three parts: (i) first we explore place, including how spatial, social, and historical contexts influence perceptions, (ii) then we explore how formal and informal processes influence engagement, and finally (iii) we provide a comparative example of differential development trajectories of wind energy in Texas and Massachusetts (USA) to demonstrate how public perceptions and engagement in different places and facilitated by different processes may lead to different patterns of LCET deployment.

\section{Methods}

This review synthesizes literature representing a wide array of interdisciplinary research. We identified research for this review through a search of journal articles, books, and reports using Web of Science and Google Scholar through January 2015. Our search used the terms "community", "public", "accept"*, "belief"*, "oppos"*, "attitude", "deliberate"*, "risk", and "govern"*. We then combined them with "energy" as well as terms describing specific energy technologies, such as "nuclear", "wind power", "coal", "biomass", and "solar". We extended our search more broadly by including terms often associated with low-carbon energy, such as "renewable" "green" or "low-carbon." We also searched commonly used acronyms such as "NIMBY" (Not in my backyard) and "LULU" (Locally unwanted land uses).

Our approach yielded over one thousand articles, spanning four decades of scholarship from fields as diverse as planning, environmental psychology, risk analysis, energy policy, and economics. After an initial sort to separate those which dealt with specific project deployment (as opposed to general perceptions of different technologies or portfolios), we divided the articles focused on project deployment into two groups. The first group addresses place, including how spatial, social, and historical contexts influence perceptions of LCETs. For example, research in this category includes analysis of demographics, landscape and prior land-use, as well as how community history influences public perceptions. The second group includes research related to processes used to site energy projects and how public engagement influences project development. This includes research on public access to information, opportunities for community involvement, historical decision contexts, and other factors. Given the wide breadth of relevant research in this area, we do not claim to be comprehensive; rather we have chosen to integrate and highlight a variety of different kinds of research with a goal of synthesizing and representing the scope of work related to deployment of LCETs.

Social science research on public perceptions of and engagement with LCETs has emphasized industrialized, Western-style democracies. While we have followed this emphasis and recognize that much of this research is more directly relevant to Western-style democracies, we have also attempted to highlight research that explores global, cross-cultural issues in more diverse contexts where many of the norms regarding the centrality of public engagement may not be shared.

\section{Place matters}

A recurring theme throughout the expansive literature on public perceptions of and engagement with LCETs is that place matters. The context of place, including cultural, economic, 
environmental, historical, political, social, and technological characteristics of place, all have potential to influence how individuals and communities perceive LCETs and how they engage in LCET development. In this section, we review research on how perceptions of LCETs are connected with both the people and the resources associated with particular places.

Perceptions of energy technologies are often associated with existing and proposed projects, but research demonstrates that place influences public perceptions beyond specific locations of projects. ${ }^{32,33}$ Dramatically different outcomes for siting energy projects have emerged in different locations, encouraging researchers to study how place shapes public perceptions. In this section, we review research connecting place and perceptions with esthetics, proximity, demographics, and history.

\section{How aesthetics of place shape public perceptions}

Over the last decade, the literature, examining relationships between people and places has grown and has been published in a wide range of journals including environmental psychology, community psychology, anthropology, urban studies, planning, economics, and others. ${ }^{33}$ People's connections with and attachments to the places where they live are critical factors influencing how individuals and communities perceive and engage with LCETs. Wolsink summarized research about opposition to LCETs, as "It's the landscape, stupid!"34 (p. 2695). Individuals and communities that attribute strong value to land preservation and the aesthetic qualities of their landscape often find the visual impacts of energy projects on the scenery unacceptable. This has sometimes resulted in conflicts among environmentalists, pitting environmental groups focused on habitat conservation and land preservation against other environmental groups promoting renewable energy. ${ }^{35,36}$ Energy projects that impact the shared aesthetic sensibilities of a community are likely to encounter opposition from the host community and others who empathize with potential host communities.

The debate surrounding the visual impact of the controversial Cape Wind project ${ }^{37,38}$ exemplifies how shared community esthetic sensibilities influence LCET deployment. In this case, which is explored in more detail in section "Perceptions and engagement in siting wind energy in the United States", placebased public perceptions became a critical component of the regulatory process and played a major role in the deliberative democratic process. ${ }^{39}$ The negative community perceptions in this case are linked to multiple concerns associated with esthetics, wildlife, economic losses, and politics. ${ }^{37}$ But a community's response and ability to mobilize effective opposition is also based upon political opportunities, civic capacity, previous experience with the technology or other development, and prior history of opposition and economic hardship, discussed further in the engagement section below. ${ }^{40}$

Within the literature on public perceptions of LCETs, the concept of NIMBY has been popular but also subject to critique. ${ }^{41-48}$ The NIMBY acronym as well as another related concept and acronym, LULU, are frequent ways to describe negative community responses to siting many facilities, from prisons to libraries, not just energy projects. ${ }^{49}$ Critics argue, however, that simplifying community perceptions with these terms masks multiple complicated factors that contribute to community opposition to proposed projects including local impacts, the type of facility proposed, and the political, economic, and environmental land-use history of the community. Some researchers claim that the NIMBY label is pejorative, simplistic, and frames those opposed to an energy project as parochial and short sighted. When used in this way, NIMBY casts any local opposition as selfish and hypocritical, and it glosses over the fact that while project benefits may be global, impacts are locally concentrated. ${ }^{42-44,50-52}$ The NIMBY concept often assumes that there is general agreement on the usefulness of the proposed facilities and that the local people are opposed simply because they would prefer not to have the project sited nearby.

Wind energy is the LCET that has been deployed at the largest scale so far, so much of the research on complexities of negative public perceptions and local opposition focus on wind. Public perceptions of wind power are related to both wind farms where energy is produced and transmission lines that move energy from where it is produced to where it is consumed. ${ }^{53-55}$ With multiple proposed wind farms, perceptions of noise, visual impacts, and other negative aesthetic effects on the landscape and proximity to homes and subsequent impact on property values have emerged as major community concerns. ${ }^{39}$ These concerns often become critical during public engagement in the siting process during which public perceptions about the technology can change. If and when project siting becomes controversial public perceptions of LCETs sometimes become increasingly polarized. For example, a Scottish study conducted in a region with a controversial proposed wind farm found that roughly $20 \%$ of survey respondents strongly opposed wind power and $28 \%$ were strongly in favor. ${ }^{56}$

Some studies indicate that direct experience with wind farms increases public acceptance, ${ }^{42,57-60}$ but others report that direct exposure to specific wind projects results in only a marginal increase in public support, and sometimes an increase in negative attitudes. ${ }^{22}$ For example, Eltham et al. found a Cornwall community's worries about visual and noise intrusion have diminished with project exposure, ${ }^{59}$ however negative experiences with on-shore wind turbines in Falmouth Cape Cod have strengthened opposition to the proposed Cape Wind off-shore project. $^{61}$

While much of the research on place-based aesthetic concerns relates to wind power, aesthetic concerns influencing public perceptions of other LCETs have also been explored. Public perceptions of solar power are generally favorable although large-scale solar farms are often perceived negatively. ${ }^{62} \mathrm{~A}$ recent study on perceptions of solar energy found limited understanding of how solar energy works among high-school students in California. ${ }^{63}$ For other LCETs that are more underground than wind and solar, the aesthetic considerations are less influential in public perception. For example, enhanced geothermal systems have received minimal opposition in part because much of the infrastructure is underground and therefore not esthetically apparent. ${ }^{64}$ Research on public perceptions of CCS, 
a nonrenewable LCET that is not well known among the public, demonstrates that perceptions are influenced by multiple social factors and aesthetic concerns are not dominant. 65,66

\section{How proximity shapes perceptions}

Results from studies of how proximity to an energy installation influences community perceptions are mixed. Some have found that proximity to projects increases positive perceptions of wind energy, ${ }^{58,60}$ while others found that proximity brought more negative perceptions. ${ }^{58,67}$ For example, Jones examined public perceptions toward wind projects, comparing residents living close to the proposed sites with a control group living farther away. ${ }^{68}$ The general attitude was similar in both groups, as was their fear of reduced real estate values and the concern that the wind project would "spoil the landscape"68 (p. 4609). Research on communities living in close proximity to wind farms in Texas highlights a diversity of perceptions. ${ }^{58}$

Perceptions of the potential benefits and risks of a project also are related to the level of trust among those close by and their perceptions of the ability of institutions to manage those risks. ${ }^{69}$ This is relevant to proximity because concerns about local impact and local-level trust are intricately linked to a community's confidence in those responsible for maintaining their health and safety. ${ }^{70}$ More generally it is increasingly acknowledged that local initiatives and spatial proximity has a critical influence on perceptions of energy innovations. ${ }^{71}$ Research on CCS has demonstrated that public perceptions are connected to spatial proximity to proposed facilities, ${ }^{72}$ although other factors, including perceptions of the need to take action on climate change, ${ }^{73}$ are also influential.

\section{How demographics of place shape public perceptions}

Another dimension connecting place and public perceptions of LCETs relates to demographics; analysis of public perceptions across demographic groups that share individual attributes reveals that demographics also influence perceptions of LCETs. ${ }^{12,56,74,75}$ Different groups tend to have different attitudes toward risk, and, therefore, different perceptions of LCETs. Reasons for beliefs about energy technologies have been analyzed by personal, socio-psychological and contextual factors. ${ }^{56,76}$ Research on personal factors includes evaluation of how age, gender, education, and income influence perceptions of LCETs. Socio-psychological variables like environmental or political beliefs (e.g., is the person a member of the League of Conservation Voters or member of the Conservative Party), knowledge level and factors like place attachment and direct experience with technologies can all shape respondent's perceptions. ${ }^{33}$ Additionally, researchers have examined how contextual or institutional factors like the size or location of projects, institutional structure, and geographic context of the project influence perceptions.

These results often highlight a complex interplay of factors shaping attitudes. For example, in a study on public attitudes on wind energy in Texas, Swofford and Slattery found that while over $93 \%$ of respondents indicated that both protection of the environment and conservation of water were important factors influencing their attitudes about wind, only $58 \%$ expressed concern about climate change and only $33 \%$ believed that the use of fossil fuels was detrimental to the environment. ${ }^{58}$ While $51 \%$ of men were concerned about climate change and $68 \%$ of women reported concern, respondents strongly favored more renewable energy use (84\%) and the use of more wind energy $(70 \%)$, highlighting that for many, addressing climate change is not the main driver supporting renewable energy development and that this can vary by gender. ${ }^{58}$

Research on risk and risk communication has found differences in how white and nonwhite populations and women and men perceive risks. These studies find that nonwhite males and all females have more similar risk perceptions than white males and that white males' risk attitudes differ from those of every other group. ${ }^{77}$ For example, from a summary of UK studies on public perceptions of energy technologies, Devine-Wright summarizes that while women report high levels of support for renewable technologies, they also are more likely to oppose specific projects and have a lower level of technology awareness. ${ }^{56}$ Additionally, a larger percentage of women oppose nuclear power than do men. ${ }^{56}$ However, gender differences are not consistent across studies. For example, Groth and Vogt found no gender difference in perceptions toward wind power in their Michigan based analysis. ${ }^{78}$

An additional demographic consideration linked to place is an individual's position and perspective within a community. A study of wind in the Netherlands found varying perceptions of wind deployment among different involved key actors; entrepreneurs tended to be concerned about the political implications of the project and streamlining the procedure, while civil servants perceptions of wind deployment were focused more on strategic initiatives including providing information and engaging with the public. ${ }^{79}$

\section{How the heritage of place influences perceptions}

An additional component of understanding public perceptions relates to the history of the place, including prior land-use as well as historical events that may have influenced public trust and risk perceptions. Land-use regulations and codes have evolved differently in different places reflecting local priorities and regional power dynamics among different actors. These different land-use regulations sometimes reflect public perceptions and priorities, but they also influence public perceptions by defining the types of processes that frame public engagement in the development of LCETs. Beyond historical land-use and regulations, a community's level of trust in an innovative new energy technology may also be related to historical experiences of that place and the cultural landscape. ${ }^{39,80,81}$ Research on public perceptions has found that levels of trust in government, industry, and the messengers (i.e., individuals and organizations who provide information to the public) are important in shaping perceptions. ${ }^{69,75}$

The history of place also relates to environmental attitudes of individuals and communities, and how those attitudes influence perceptions of LCETs. Heberlein's book on 
environmental attitudes explains why environmental problems cannot be solved simply by changing people's attitudes. ${ }^{82}$ This message extends to energy technology change too; attitudes toward energy technologies include both cognitive (where more of the research has focused) and emotional dimensions. Although research into emotional dimensions of environmental attitudes is less common than research focusing on cognition, it is clear that people's emotional connections to a place are based on their historical experiences in that place. Cultural perceptions of landscape are difficult to assess and are connected to people's emotional connections to the place where they live which is based on their historical experiences in that place and their cultural perceptions of the landscape.

A critical point in the research on attitudes is that emotion can make individuals' attitudes impervious to change, and an emotional shift can also result in drastic shifts in attitudes. ${ }^{82}$ In considering the role of emotion in risk perception, there are two dominant theories: (i) people are generally irrational and their emotional apprehensions are erroneous, and (ii) emotional apprehensions are meaningful and valuable. ${ }^{83}$ The first perspective dismisses lay people's fear and calls for a greater role in expert risk evaluation to counteract the public's irrationality. The second perspective places value in emotional reactions and offers space for people's perceptions (whether perceived as rational or irrational to others) to be integrated into decision-making. ${ }^{83}$ The relative influence of these two perspectives on public perceptions of LCETs connects with the historical experiences of individuals, communities, and energy technology developers.

\section{Process matters}

Those who wish to develop, deploy, and site LCETs need to develop appropriate social processes for engaging host communities and other individuals who live in or care about the place. Much of the social science research on public engagement focuses on describing and critiquing different engagement processes. This research ranges from descriptions of individual techniques to critical analyses of the conceptual frameworks (such as the deficit model, see Ref. 84) that guide both process design and development of engagement materials. Whether social science is primarily conducted to describe existing public engagement processes, or to recommend ways to improve future processes, much of the research tends to be project specific. This emphasis has emerged out of conceptual and policy frameworks noted in the section "How the heritage of place influences perceptions", and further explained here.

\section{How models of public participation influence process}

As social demands on the electricity system have expanded beyond ensuring access, reliability, and affordability to now also including a suite of environmental and economic benefits, the challenges of designing and managing appropriate public processes have become a central concern for many government agencies, industries, and interest groups. This shift places the electricity system at the center of a type of policy problem
Meadowcroft ${ }^{85}$ identified as being marked by high complexity and the potential for intense conflict. Public engagement processes for LCETs, especially those focused on deployment and siting, have the potential to influence acceptance, indifference, or opposition to specific technologies, and even entire systems.

Public participation (PP) generally refers to communication between an organization responsible for a decision and members of the public who may be impacted by that decision. The most common approaches are written public comment periods and public hearings. Other frequently used approaches include listening sessions, workshops, and various consensus-based processes. ${ }^{86}$ Although Arnstein ${ }^{87}$ described PP as a redistribution of power from government to individual citizen, that redistribution may be minimal and is not necessarily an essential component of PP. The degree of involvement may range from being allowed to read material produced by project advocates to participating in forums that provide opportunities for individual actors engage with others to explore mutual values and interests, even influencing systemic change. ${ }^{88}$ Essentially, public involvement still spans a broad range, from the right to know what information was used to arrive at a decision, to direct participation in decisions that may change entire systems. ${ }^{86}$

Policy frameworks in many countries require implementation of some sort of public involvement process as part of gaining approval for projects that have the potential to raise significant environmental issues, and energy development falls within this purview. A second reason that research on public engagement processes tends to be project specific is that as noted in the previous section, the lay public tends to ignore energy until a particular project is proposed for local siting. At that point, public interest in the specific technologies associated with the project develops rapidly, and the associated perceptions may be positive or negative, as well as accurate or inaccurate.

Although a thorough discussion of the policies that shape public engagement processes for LCET development and deployment is beyond the scope of this review, a few examples illustrate the point. The U.S. National Environmental Policy Act (NEPA) is historically probably the most significant national law currently mandating PP. Although legal jurisdiction is limited to the United States, "NEPA's influence has been far-reaching, with its progeny in the statute books of 19 states and over 130 of the world's nations"89 (p. 275). Within the United States, NEPA establishes minimum requirements for PP, including scoping of citizen preferences, notification through the Federal Registry, response to all public comments submitted during a specific time period, and argumentation for selection of the final option. NEPA influences energy project siting as well as many other types of developments. The Aarhus Convention (formally UNECE Convention on Access to Information, PP in Decision-making and Access to Justice in Environmental Matters), which entered into force in 2001, moved beyond NEPA to mandate that governments incorporate PP into all decisions regarding environmental matters in over 40 European and Central Asian countries, the European Union, and the European Community. ${ }^{90}$ Most of these laws, however, do not specify when, and in what ways the public will participate. 
Connections between process and LCETs tend to emerge at the project level because as community members actively engage with LCET siting, engagement becomes a salient issue for project success. At this point, the process of engagement becomes as important as individual perceptions, and firms contemplating million or billion dollar investments have attempted to design processes that encourage public support. People may participate in both formal and informal processes, ranging from public hearings through community meetings, to public rallies. Although project proponents may be tempted to design PP processes to allow only the minimum amount of legally mandated public involvement so that a project can move forward quickly, this approach may backfire and result in stronger public opposition later. ${ }^{91}$

Participation in formal decision-making processes happens through multiple different mechanisms and venues. Citizens testify before county zoning boards, city councils, state Public Utility Commissions, and at state legislative hearings. The public may formally participate in legislative, regulatory, and administrative hearings, court cases, and administrative appeals. Public receptivity to these engagement processes has not been universally positive. Members of the public often complain that the information they receive is too technical or irrelevant, that agencies have determined the outcome of the situation before involving the public, and that agencies do not make sufficient effort to identify and involve affected stakeholders. Citizens can also protest energy projects outside of traditional administrative channels through marches and demonstrations and increasingly, using electronic and multimedia tools to reach broader audiences and shape the debate, as discussed in section "How process relates to public engagement with energy projects".

\section{How process relates to perceptions (attitudes, risks, and values)}

Both acceptance of and opposition to LCET projects are associated with process in addition to place. In their rhetorical analysis of opposition to wind farm siting, Barry et al. ${ }^{92}$ found that those whose opposition had been vilified as NIMBYism were displaying cultural (rather than technical) rationality, which places a premium on value-based decision making and the credibility of decision makers. Their opposition was largely based on personal, familial, and community relationships and the belief that these long-standing relationships had not been considered in decisions to introduce wind turbines into the landscape. Hall et al. provide another example of this process-related problem in an Australian context. ${ }^{93}$ Devine-Wright and Howes ${ }^{52}$ argue that strong place attachment can lead to "negative attitudes and oppositional behavior" regarding wind farm projects, and that "levels of trust in key actors moderated the relation between place attachment and negative attitudes" (p. 271). Their findings indicate that, in situations where residents feel a strong place attachment, designing and facilitating an acceptable public involvement process is crucial to project success. This suggests that NIMBYism is far more complex than a simple desire to have projects sited elsewhere but is a deeply situated personal and social response to the siting process. The right process can help LCET project supporters understand and then respond to emotive dimensions of decision making. Indeed, strong place attachment does not always equate to opposition toward landscape change. Rather, Devine-Wright and Howes ${ }^{52}$ suggest that decision makers can influence public acceptance by designing and implementing processes that moderate how individuals interpret change and how well they accommodate disruption to place attachment.

Planners and decision-makers sometimes reduce problems with LCET siting to a simplistic view of communication failure. ${ }^{94}$ Often these planners and decision-makers assume that if only opponents had the same information that they had, they would be supportive; this common assumption has been termed the "deficit model." This view presumes that the primary purpose of communication is to remediate the deficit in public understanding of science and technology. From this perspective, public processes should make the public become more aware, better informed, or less ignorant of the potential benefits of LCETs, thus opening the path for acceptance. Wolsink ${ }^{34,94}$ contends that processes grounded in this perspective are unlikely to contribute substantially to public support, because public concerns about local plans are determined largely by local perceptions of local conditions, and these perceptions may differ from, without being inferior to, perceptions of project developers, or scientists and engineers.

Much of the research on public perceptions has also been based on a deficit model, assuming that lack of acceptance for new technologies results from the lay public's deficit of knowledge. This research often presumes that if the perceived gaps in technical knowledge were filled, stakeholders would become supportive of implementing the technology. ${ }^{84}$ When this perspective is applied, process developers and facilitators assume responsibility for ameliorating the public deficit in knowledge. Firestone and Kempton ${ }^{95}$ illustrate the deficit model when they argue that, "support (for off-shore wind power) would be enhanced by a more complete understanding of both the negative and positive environmental impacts" (p. 1597). In an article that otherwise offers rich suggestions for engaging with publics from their own perspectives, the authors ultimately return to the deficit model, claiming that if only publics more fully understood the science behind a project they would be more likely to accept it. Further, they offer project proponents an excuse that may be comforting but is unlikely to contribute to increased mutual understanding: "Sometimes, public perceptions are so different from those of scientists and analysts that they are difficult to understand" (p. 1597). Our point here is not that the deficit model is wrong, but that it is inadequate. Certainly, "a more complete understanding" of any technological system is desirable, but the idea that public processes should facilitate increased understanding only by remediation of the public deficit leaves out at least two important components. First, residents may have local knowledge that would be valuable to the professionals who have proposed a project. And, second, the professionals who design, develop, and advocate for LCET projects are also citizens.

Public relations research has taken up crises to draw out best (and worst) practices for energy development, particularly in 
terms of legitimation that largely goes unnoticed as an image management issue until a crisis hits. ${ }^{96}$ Such research emphasizes the importance of an anticipatory model for crisis communication so that energy companies' communications in times of crises are interpreted more favorably. ${ }^{97}$ Case studies show how strategies for communicating with the public should differ at varied stages of crisis, ${ }^{98,99}$ and how strategies useful in one instance may be less successful in another. For example, Cotton et al. ${ }^{100}$ demonstrated how TEPCO, the Japanese power company held responsible for the Fukushima Daiichi disaster, failed in their attempts to refurbish their organizational image due to inappropriate framing strategies before and after the crisis. Research on best practices for the coal industry notes its relatively widespread success in marketing "clean coal" as a LCET by emphasizing CCS. ${ }^{101,102}$

\section{How process relates to shifting media environments}

Recognizing the growing importance of engaging the public via electronic media, Chewning ${ }^{103}$ also recommended the creation of intermedia dialogs so that the same narrative circulates across media platforms. Interactive media are produced by both amateurs and professionals and distributed via multiple platforms. This makes content widely accessible by anyone interested, even those not in the immediate region of a LCET project. ${ }^{104}$ These shifts in media and technology have changed how the public engages in energy related decisions. In the past, public involvement processes were limited to face-to-face meetings and paper-based campaigns. These techniques have been supplanted by chat rooms, blogs, Facebook pages, Instagram, and Twitter-feeds. ${ }^{105}$ The main point is that people interested in LCET siting decisions have new tools that can be combined with more traditional approaches. Publics have access to information through multiple networks that can easily distribute policy briefings, viral videos, and other materials. These tools can be used to support and to oppose LCET projects and initiatives. ${ }^{31}$

More traditional media continue to play an important role in public processes. ${ }^{106}$ Media coverage is shaped by and shapes policy and public opinion in many ways. ${ }^{107-112}$ Newspapers, television, and radio continue to influence, inform, and shape public perceptions and conversations about LCETs. News outlets report on technological and social developments, policy issues, and energy-relevant financial ventures, as well as providing opinion pieces aimed at shaping public perceptions. ${ }^{113,114}$ Media coverage influences the likelihood of PP in processes designed to engage people in LCET projects by contributing to a project's salience. ${ }^{115,116}$ With issues such as LCETs, media often bridge between technical and sociopolitical assessments. ${ }^{116-119}$ Topic choice and framing can influence how publics understand particular technologies and projects, because most people experience new technologies through media coverage rather than directly. ${ }^{120}$ Because media have large potential to influence public perceptions and beliefs, processes for engaging publics should consciously assess mediated conversation as part of project development. ${ }^{121}$ For example, recent analysis of fracking in Germany traces two conflicting narratives that represent pro (the golden age of gas) and con (water pollution) sides of the fracking controversy. ${ }^{122}$ Research on media coverage of LCETs ${ }^{110,121-126}$ demonstrates that potential participants in public processes enter any process within a context largely constructed by the media. This context includes interactions between cultural, economic, environmental, political, and technological dimensions of society. ${ }^{111,112,127,128}$

\section{How process relates to public engagement with energy projects}

Several researchers have expanded the study of public processes involved in siting decisions beyond notions of ameliorating public deficits and top-down marketing as means of persuasion. Some research on PP in energy futures argues for models that go beyond simplistic expectations of producing public acquiescence as a result of remediating a deficit or marketing new products. This research suggests publics should be brought into conversation much earlier in the decision making process, ${ }^{129-131}$ and that local publics may even bring important knowledge to the table. ${ }^{132}$ For example, Davies and Selin ${ }^{129}$ point out common tensions that emerge in energy deliberation and argue for the value of an anticipatory governance framework across multiple energy technologies. Some research indicates that public processes will be more effective if they include overt attempts to understand the mental models of the multiple publics that see themselves as impacted by a technology or a project. ${ }^{133}$ This provides a first step toward harmonizing mental models held primarily by technical experts with models held by members of the lay public. Processes that consider the mental models of all those involved in a process have strong potential for bridging gaps between different groups. ${ }^{134}$

Engagement with energy projects at the community level links project developers with local community members. One of the most important factors to emerge from the literature on engagement is the concept of procedural justice. For example, Zoellner et al. found that an engagement process was more likely to be successful if it could demonstrate ${ }^{135}$ :

(i) Consistent or equal treatment across individual people and situations,

(ii) Absence of self-interest on the part of those coordinating the process, and

(iii) Adherence to basic moral and ethical values.

The process should also provide:

(iv) Accurate information,

(v) Opportunities for representation for all interested parties, and

(vi) The possibility for participants to change their minds.

They also found that people were more likely to accept projects from companies that had previously demonstrated their commitment to the locale. Procedural justice is not as easy to demonstrate as it may seem. For example, in southern Evia in Greece, while respondents' support of wind energy was strong, people were disappointed by the limited opportunities of engaging with public and private institutions, and they believed the information they received was too limited. ${ }^{136,137}$ 
Maille $^{\prime}$ and Saint-Charles ${ }^{138}$ studied information diffusion in Quebec, and concluded that citizen hostility to a wind farm stemmed largely from the belief that project promoters had strategically excluded them from the process. Fenton et al., ${ }^{139}$ who studied stakeholder engagement processes in energy development and climate change strategies in 60 municipalities throughout Sweden concluded that the most generalizable principles for effective public process were to engage with stakeholders early, frequently, and completely.

Sometimes projects encounter opposition for economic reasons. Zoellner et al. ${ }^{135}$ also found that individual cost-benefit calculations were one of the strongest predictors of project acceptance, indicating that immediate self-interest remains important to acceptance of LCETs. One of the main arguments for local development of energy projects is the generation of local economic benefits, including jobs, ${ }^{48,60,140}$ but how local communities perceive their own potential to reap these benefits can shape a community's perception of the project. For example, in an analysis of wind development in Wales, Munday et al. found that most of the economic benefits of wind development have not gone to local communities and this can shift public perceptions of projects. ${ }^{140}$ Warren and McFadyen ${ }^{141}$ surveyed Scottish residents to test whether community owned wind-farms positively influenced local attitudes toward wind farms and found that local ownership did increase positive attitudes toward wind power. Community co-ownership was found to positively affect perceptions in Southern Germany, ${ }^{142}$ but different financial mechanism dominates in different locations. For example, in Spain, over $95 \%$ of projects are owned by public-private partnerships and this mechanism has been identified as critical for wind development there. ${ }^{143}$

Successful processes work together with culture, economics, and politics at local, national, and even international levels. For example Toke et al. ${ }^{144}$ studied the relationships of planning systems, financial support, landscape protection groups, and patterns of ownership to compare the development of wind energy in England, Denmark, Spain, the Netherlands, and Germany. These researchers highlight the importance of the national context in shaping local siting decisions and the relative power/ability of local communities to change energy technology development patterns. Engagement opportunities and preferences vary widely. In most North American and European contexts, members of the lay public expect opportunities to engage within the planning and siting process. The value of widespread public involvement in energy development also has been noted in other regions. For example, in 2000, Peru became a medium-range gas exporting country. Its energy policy, which had previously been highly centralized, now relies on consensus processes that ensure citizens are integrated in and engaged with increased horizontal and decentralized decision making. Fontaine ${ }^{145}$ found that this shift contributed to environmental and economic sustainability, as well as to positive working relationships between the State, energy companies, NGOs, and indigenous communities.

In all of these situations, the ideals of deliberative democracy and the importance of public engagement in local decisions have become important to energy governance and siting. ${ }^{80}$ For example, in Denmark, renewable energy development and the creation of a low-carbon smart grid aligns with national energy policy and social consciousness and contributes to the Danish goal of replacing fossil fuels with local, renewable energy, as well as the global need to mitigate anthropogenic climate change. The deployment of EcoGrid EU on the Danish island of Bornholm illustrates the importance of integrating culture, economics, and politics at multiple jurisdictional levels into LCET deployment. ${ }^{31}$ EcoGrid EU aligned with both national goals to minimize dependence on imported fossil fuels and local goals to ensure continued access to electricity when links to the sub-sea cable connecting the island to the larger grid are inadvertently cut. Educational materials noted this alignment and "appealed more to good citizenship rather than narrow financial gains"146 (p. 32). Dieter Gantenbein, a smart grid researcher with IBM-Zurich explained, for Danes "preservation of the environment, It's like a sport. They use different technologies, and by being engaged, they are very enthusiastic to participate in such an ambitious pilot"147 (p. 6). Building on this idea, volunteer recruitment focused on social and environmental values, emphasizing that participants would be helping develop an eco-friendly electrical system. This orientation also shaped project claims, volunteers were promised that they would not pay more to participate, but they were not promised that they would save money.

\section{Why process matters to LCET futures and innovative ways forward}

One reason that process matters so much to the future of LCETs is that the form of engagement can either encourage or discourage deployment. This is especially the case with technologies that are associated with politically controversial topics. LCETs are especially vulnerable to political ideology, because much of the justification for their deployment comes from the argument that anthropogenic climate change is real and problematic. Within the United States, for example, this remains a controversial claim and is subject to political manipulation. ${ }^{148,149}$ For example, Fletcher noted that the frame of scientific skepticism has been used to justify U.S. inaction on climate change, while the frame of security threat has challenged the validity of inaction. She argued that a frame of economic opportunity could offer a way out of the stalemate, largely due to its strong positive link to technological optimism, or the assumption that new technology will enable industrial transformation to remedy past mistakes. ${ }^{150}$ Indeed, framing of wind projects in states like Texas has largely emphasized economic development. ${ }^{151}$

Building from the same logic, some researchers advocate meeting publics where they are, rather than waiting until they change their political ideologies or become more technically educated. For example, in the United States, those who oppose investment and development of LCETs have successfully framed climate change as a struggle between good and evil, rather than as a practical problem that needs to be confronted. While scientists and engineers can be uncomfortable with such dramatic framing, Feldpausch-Parker et al. ${ }^{152}$ suggested that since drama resonates with the public, one way of engaging the lay public is 
to tap into people's tendency to conceptualize issues in terms of a struggle between heroes and villains. They developed and tested an educational video game that frames anthropogenic $\mathrm{CO}_{2}$ emissions as the villain and humans as heroes who use science and technology to mitigate anthropogenic climate change. Students who played the game experienced a knowledge increase that suggests options for productively reframing climate change toward an emphasis on technological mitigation through LCETs.

Public engagement can take many nontraditional forms. For example, Perreault and Valdivia ${ }^{153}$ found that struggles over hydrocarbon governance and resource development in Ecuador and Bolivia both relied on and contributed to evolving meanings for human development and national identity. Although more traditional discussions such as competition for scarce resources remained important, theatrical performances by popular movement activists helped people to re-imagine the nation-state and the benefits and costs of hydrocarbon development.

\section{Perceptions and engagement in siting wind energy in the United States}

Place and process work together to shape the development of new socio-technical systems. Here, we illustrate our claims by providing a more extended review of social science research on public perceptions of and engagement with the siting of LCET. We compare the literature on two very different contexts for development of wind resources and siting in the U.S. states of Texas and Massachusetts. While both states have adopted policies to support the development of renewables, siting and building wind projects in Texas has been relatively easy, while development in Massachusetts, particularly the high profile Cape Wind project has been fraught with challenges. This is particularly interesting, as the renewable energy policy environment in Massachusetts, at least on paper, appears much stronger than in Texas. ${ }^{151}$ These two cases highlight how LCET technology implementation is being shaped by the different contexts for energy development and how local siting decisions are shaped by land use and culture.

Both states share the same national context supporting wind power R\&D and projects benefit from U.S. policies like the production tax credit. In the mid 2000 's twenty-nine U.S. states including Texas and Massachusetts passed renewable portfolio standards (RPS) to further support deployment of renewable energy technologies. The Massachusetts law requires $22 \%$ of electricity to come from renewable sources by 2020 , with an explicit goal of installing 2000 MW of wind power, while the Texas legislation was much less aggressive, targeting just 2000 MW of wind development by 2009 initially. Both states have strong wind resources, but developing wind projects has varied significantly in these states. ${ }^{53,127,151,154}$

Currently, Massachusetts has just 107 MW of wind power with none under construction and with wind providing less than $0.7 \%$ of electricity production; wind power in Massachusetts has become embroiled in multiple siting struggles. In contrast, Texas has become the poster child for the North American wind industry with 14,208 MW of installed capacity and another 7805 MW under construction. In Texas, wind power now provides $9 \%$ of in-state electricity, which is supported by billions of dollars in new transmission investment and is integrated into the regional wholesale energy market run by the Electric Reliability Council of Texas. These two dramatically different fates have been influenced more by public perceptions shaping the ability to site and construct projects than by specific legislation. This section explores how these divergent contexts are facilitating rapid deployment of wind power in one location and minimal slow deployment in the other.

Within the United States, Texas is perceived as an "energy state," with a long and extensive history of both fossil energy production and wind power deployment. ${ }^{155}$ Wind power has a long history in Texas, used since the 1880 s to pump water and oil. State policies to promote modern wind power began in 1999 when Governor George W. Bush signed Senate Bill 7 in 1999 , which established Texas' RPS. But few could have predicted the rapid pace of wind development in Texas. By 2007, over $4000 \mathrm{MW}$ of wind power had been installed, twice the original RPS goal. The Texas legislature revised the RPS, setting a target of 5880 MW by 2015 and 10,000 MW by 2025 . Both of these goals were surpassed by 2013 and were supported by high levels of public acceptance which facilitated siting as well as other factors like relatively high natural gas prices (until 2010) which made wind power comparatively inexpensive. Additionally, Texas politicians supported the development of additional transmission infrastructure and grid operators worked to integrate wind power into energy markets. ${ }^{31}$

Throughout, local support for wind power in Texas has remained strong. ${ }^{58,156-158}$ Local economic benefits have aided the development of the resource ${ }^{158}$ and shaped the political discourse supporting wind power. ${ }^{53,127,154}$ Indeed, in Texas, wind deployment is not driven by efforts to reduce greenhouse gas emissions. ${ }^{58}$

In contrast, wind power development in densely populated Massachusetts has proven much more controversial. In Massachusetts, siting wind projects both on-shore and offshore has proven to be challenging. Some speculate that the relatively densely populated wealthy communities are upset by their scenic mountain or sea vistas despoiled by wind developments. Opposition often focuses on esthetics, but also includes noise pollution, and natural resource disruption. ${ }^{39}$ The permitting process has been one mechanism by which opposition to wind projects has been formalized. Indeed, the contentious Cape Wind project has become emblematic of the challenges facing energy technology deployment. ${ }^{37-39,159-162}$ Located off the wealthy and picturesque Nantucket Sound in the shallow Horseshoe Shoals, the 468 MW off-shore project has been fighting opponents for over a decade. ${ }^{37}$ First proposed in 2001, it took 10 years for the developers of Cape Wind to get federal and state permits and they have won 17 legal decisions challenging multiple aspects of the proposed project including permitting approvals, power purchase agreements, Federal Aviation Administration approvals, state and local permits. High-profile and powerful opponents include 
Governor Mitt Romney, Senators Kennedy (MA) and Warner (VA), industrialist Bill Koch and media figurehead Walter Cronckite. The opponents cross political party lines and have come from the public and private sectors to fund opposition groups like Save our Sound and the Alliance to Protect Nantucket Sound. In early 2015, after Cape Wind missed several contractual deadlines, the electric utilities that had agreed to purchase the power withdrew from the project leaving little hope for the project's future. On-shore wind projects in Massachusetts have also faced strong opposition and local controversy. Two on-shore installed wind turbines in the town of Falmouth have divided this community as opponents advocating to have the municipal turbines taken down. Even wind turbines owned by a local cooperative, the Berkshire Wind Power Cooperative, which operates a 15 MW 10 turbine farm on Brodie Mountain, has faced considerable local opposition.

Wind energy development in these two states highlights the dramatically different contexts for LCET development. ${ }^{127}$ The 2013 median household income for a 4-person family in Massachusetts is $\$ 106,000$, while Texas is $\$ 69,500 .^{163}$ In Texas, wind power squares well with the cultural context of the state as an energy producer; wind projects have been frequently framed and viewed as engines for local economic development. For wealthier Massachusetts, the economic advantages of wind power development may not overcome the esthetic impacts or other perceived negative implications. ${ }^{154}$

Population density differences could affect siting as well. While the state average for Texas is 40 people $/ \mathrm{km}^{2}$, in the areas with wind development it is often less than 0.25 people $/ \mathrm{km}^{2}$. In Massachusetts, 331 people $/ \mathrm{km}^{2}$ is the average density, in the Western areas where wind development is occurring it is still 40 people $/ \mathrm{km}^{2}$. Siting wind projects in sparsely populated communities in Texas is much less controversial as it has in more densely populated Massachusetts. ${ }^{154}$

Massachusetts also highlights how intensely political LCET siting can become and how the process can be used by opponents to slow and block projects. The Cape Wind project has involved prominent and influential people shaping federal and state legislation, funding nonprofits, and challenging the project in court. Opponents have used multiple venues in the siting and project development process to block the project. By contrast, wind development in Texas has not been subjected to either this level of political and public strife and has proceeded (relatively) smoothly.

\section{Discussion and conclusions}

Both place and process matters for LCET development. Although it would simplify things if we could equate place with material reality and process with socially constructed reality, that oversimplification would be counterproductive. Indeed, the meaning of place is socially constructed. And processes used to engage people with development and deployment of LCETs are constructed through interactions among individuals and groups. Together place and process shape material realities, such as the relative influence of various stakeholders and determine the feasibility of projects.
Who benefits from LCET development and who pays the perceived costs from new projects is not always clear. While the project developer may benefit financially, and the local community may gain a few jobs, the community hosting the project may not believe these benefits offset the project costs. The value in project development of local ownership and/or direct local benefits (the leasing of land for wind turbines in many parts of the U.S. Midwest for example) has been widely recognized, and research examining different project ownership models seeks to examine if community ownership models enhance public acceptance. ${ }^{164}$ In theory, community ownership of LCET projects would have clearer direct benefits to the host community and improve local perceptions of energy projects. Several studies have evaluated the role of different ownership models in developing renewable energy projects, with most of the literature focused on wind development.

It is useful to remember that building the energy system has always required negotiating across multiple viewpoints and interests. The 1937 Federal Theater Project play Power, explored the negotiation between system access, affordability, and the tensions between government and private industry. ${ }^{165}$ At the time, private companies were charging up to $0.20 / \mathrm{kWh}$, or $\$ 3.26 / \mathrm{kWh}$ in today's dollars and many areas of the country, such as the Tennessee Valley did not have access to electricity. The play explores the contested political space surrounding the creation of the Tennessee Valley Authority, which promised that municipalities could sell its hydro-generated power at $0.03 / \mathrm{kWh}$ (0.49/kWh in today's dollars). Progressive politicians like Republican Senator Norris from Nebraska fought to ensure electricity was affordable and accessible for U.S. citizens. The Congressional and resulting legal battles continued for decades and eventually ended up in the Supreme Court.

This review has focused on the importance of place and process in industrialized Western democracies and we recognize that LCET acceptance and deployment in nondemocratic regimes likely follows very different pathways. Many of the policy and procedural values which underlie LCET deployment in the Organization for Economic Co-operation and Development (OECD) are not shared in other countries. Further research to map the contours of LCET development in the developing world and in nondemocratic regimes is needed and would be a welcome addition to existing scholarship.

Unfortunately, much of the discussion about, and processes for, public engagement with LCET project development remains philosophically grounded in the deficit model. It implicitly assumes that people's failure to accept an LCET project is caused by their lack of understanding. To counter this project proponents often prepare materials presenting LCET project facts. We hope this review of other factors shaping the underlying frames and processes for public engagement with LCET projects encourages inclusion of this broader literature into project planning. Some LCET projects develop very creative ways to engage with local publics and shape their perceptions at deeper levels than relying solely on a fact-based approach.

Within the research community there are also tensions between social scientists, who are trained to be "neutral observers" when studying social phenomena, and technology 
focused researchers, who are actively working toward accelerating a shift in the dominant technological regime. This tension affects both choice of research topics, intellectual framework, and engagement with stakeholders.

Across much of the world, LCET project deployment is proceeding at a pace faster than critics or proponents ever imagined possible. The changing role of LCETs means that energy systems now regularly operate in ways that were deemed impossible just a decade ago, with some places aiming for $100 \%$ renewable energy production. ${ }^{166}$ In other places, the lack of LCET development is slowed by public perceptions and a contested approval process. In this study, we have detailed the academic literature underlying these different contexts and explore the different forces shaping these environments. Careful examination of both place (where the project is located) and process (how the public engages with LCET development and siting) provides significant opportunities for understanding the complex social contexts shaping the future of sustainable energy systems.

\section{REFERENCES:}

1. Miles R.: The origin and meaning of Miles' Law. Public Adm. Rev. 38(5), 399-403 (1978).

2. National Academy of Sciences, National Academy of Engineering, and National Research Council, America's Energy Future, ed. National Academies of Sciences. 2009, Washington DC.

3. Brown L., Larsen J., Roney J.M., and Adams E.E.: The Great Transition: Shifting from Fossil Fuels to Solar and Wind Energy (Earth Policy Institute, W.W. Norton, New York, 2015).

4. Baker R.: Energy policy. In The Problem of Public Perception, in Energy, Science, Policy, and the Pursuit of Sustainability, Bent R., Orr L., and Baker R. eds.; Island Press: Washington, DC, 2002.

5. Furby L., Slovic P., Fischhoff B., and Gregory R.: Public perceptions of electric power transmission lines. J. Environ. Psychol. 8(1), 19-43 (1988).

6. Barke R.P. and Jenkins-Smith H.C.: Politics and scientific expertise: Scientists, risk perception, and nuclear waste policy. Risk Anal. 13(4), 425-439 (1993).

7. Farhar B.C.: Trends in US public perceptions and preferences on energy and environmental policy. Annu. Rev. Energy Environ. 19(1), 211-239 (1994).

8. Poumadere M., Mays C., Slovic P., Flynn J., and Johnson S.: What lies behind public acceptance? Comparison of US and French perceptions of the nuclear power option. In The Nuclear Power Option. Proceedings of an International Conference on the Nuclear Power Option Held in Vienna, 5-8 September 1994, 1995.

9. Gustafson P.E.J.: Gender differences in risk perception: Theoretical and methodological perspectives. Risk Anal. 18(6), 805-811 (1998).

10. Sjöberg L.: Attitudes and risk perceptions of stakeholders in a nuclear waste siting issue. Risk Anal. 23(4), 739-749 (2003).

11. Palmgren C.R., Morgan M.G., de Bruin W.B., and Keith D.W.: Initial public perceptions of disposal of $\mathrm{CO}_{2}$. Environ. Sci. Technol. 38(24), 6441-6450 (2004).

12. Poortinga W., Pidgeon N., and Lorenzoni I.: Public Perceptions of Nuclear Power, Climate Change and Energy Options in Britain: Summary Findings of a Survey Conducted during October and November 2005. Tyndall Centre for Climate Change Research. School of Environmental Sciences. University of East Anglia, 2006.

13. Shackley S., Mander S., and Reiche A.: Public perceptions of underground coal gasification in the United Kingdom. Energy Policy 34(18), 3423-3433 (2006).

14. Carr-Cornish S. and Romanach L.: Differences in public perceptions of geothermal energy technology in Australia. Energies 7(3), 1555-1575 (2011).
15. Poumadère M., Bertoldo R., and Samadi J.: Public perceptions and governance of controversial technologies to tackle climate change: Nuclear power, carbon capture and storage, wind, and geoengineering. Wiley Interdiscip. Rev.: Clim. Change 2(5), 712-727 (2011).

16. Mah D.N-y., van der Vleuten J.M., Hills P., and Tao J.: Consumer perceptions of smart grid development: Results of a Hong Kong survey and policy implications. Energy Policy 49, 204 (2012).

17. Chaudhry R., Fischlein M., Larson J., Hall D.M., Peterson T.R., Wilson E.J., and Stephens J.C.: Policy stakeholders' perceptions of carbon capture and storage (CCS): A comparison of four U.S. States. J. Cleaner Prod. 52, 21-32 (2013).

18. Reiner D.M., Curry T.E., Figueiredo M.A.d., Herzog H.J., Ansolabehere S.D., Itaoka K., Johnsson F., and Odenberger M.: American exceptionalism? Similarities and differences in national attitudes toward energy policy and global warming. Environ. Sci. Technol. 40(7), 2093-2098 (2006).

19. Upreti B.R. and van der Horst D.: National renewable energy policy and local opposition in the UK: The failed development of a biomass electricity plant. Biomass Bioenergy 26(1), 61-69 (2004).

20. Upham P. and Shackley S.: Local public opinion of a proposed 21.5 MW (e) biomass gasifier in Devon: Questionnaire survey results. Biomass Bioenergy 31(6), 433-441 (2007).

21. Kaldellis J.K., Kapsali M., Kaldelli E., and Katsanou E.: Comparing recent views of public attitude on wind energy, photovoltaic and small hydro applications. Renewable Energy 52, 197-208 (2013).

22. Kontogianni A., Tourkolias C., Skourtos M., and Damigos D.: Planning globally, protesting locally: Patterns in community perceptions towards the installation of wind farms. Renewable Energy 66, 170-177 (2014).

23. Conway F., Stevenson J., Hunter D., Stefanovich M., Campbell H., Covell Z., and Yin Y.: Ocean space, ocean place: The human dimensions of wave energy in Oregon. Oceanography 23(2), 82-91 (2010).

24. Scheer D., Konrad W., and Scheel O.: Public evaluation of electricity technologies and future low-carbon portfolios in Germany and the USA. Energy Sustainability Soc. 3(1), 1-13 (2013).

25. Rosa E.A. and Dunlap R.E.: Poll trends: Nuclear power: Three decades of public opinion. Publ. Opin. Q 58(2), 295-324 (1994).

26. Carley S.R., Krause R.M., Warren D.C., Rupp J.A., and Graham J.D. Early public impressions of terrestrial carbon capture and storage in a coal-intensive state. Environ. Sci. Technol. 46(13), 7086-7093 (2012).

27. Pidgeon N.F., Lorenzoni I., and Poortinga W.: Climate change or nuclear power: No thanks! A quantitative study of public perceptions and risk framing in Britain. Global Environ. Change 18(1), 69-85 (2008).

28. Walker G.: Renewable energy and the public. Land Use Policy 12(1), 49-59 (1995).

29. Bolsen T. and Lomax-Cook F.: The polls-trends: Public opinion on energy policy: 1974-2006. Publ. Opin. Q 72, 364-388 (2008).

30. Sandfort J. and Moulton S.: Effective Implementation in Practice: Integrating Public Policy and Management (Jossey-Bass, San Fransisco, CA, 2015).

31. Stephens J.C., Wilson E.J., and Peterson T.R.: Smart Grid (R)Evolution: Electric Power Struggles (Cambridge Press, Cambridge, 2015).

32. Devine-Wright P.: Place attachment and public acceptance of renewable energy: A tidal energy case study. J. Environ. Psychol. 31(4), 336-343 (2011).

33. Lewicka M.: Place attachment: How far have we come in the last 40 Years? J. Environ. Psychol. 31, 207-230 (2011).

34. Wolsink M.: Planning of renewables schemes: Deliberative and fair decision-making on landscape issues instead of reproachful accusations of non-cooperation. Energy Policy 35(5), 2692-2704 (2007).

35. Warren C.R., Lumsden C., O’Dowd S., and Birnie R.V.: "Green on green": Public perceptions of wind power in Scotland and Ireland. J. Environ. Plann. Manage. 48(6), 853-875 (2005).

36. Lovich J.E. and Ennen J.R.: Wildlife conservation and solar energy development in the desert southwest, United States. BioScience 61(12), 982-992 (2011).

37. Williams W. and Whitcomb R.: Cape Wind: Money, Celebrity, Class, Politics, and the Battle for Our Energy Future on Nantucket Sound (Public Affairs, New York, 2007). 
38. Kemtpon W., Firestone J., Lilley J., Rouleau T., and Whitaker P.: The offshore wind power debate: Views from Cape Cod. Coastal Manage. 33(2), 119-149 (2005).

39. Phadke R.: Steel forests or smoke stacks: The politics of visualisation in the Cape Wind controversy. Environ. Polit. 19(1), 1-20 (2010).

40. McAdam D. and Boudet H.: Putting Social Movements in Their Place: Explaining Opposition to Energy Projects in the United States, 2000-2005 (Cambridge University Press, Cambridge, UK, 2012).

41. Ellis G., Barry J., and Robinson C.: Many ways to say 'no', different ways to say 'yes': Applying Q-methodology to understand public acceptance of wind farm proposals. J. Environ. Plann. Manage. 50(4), 517-551 (2007).

42. Devine-Wright P.: Beyond NIMBYism: Towards an integrated framework for understanding public perceptions of wind energy. Wind Energy $8(2)$, 125-139 (2005).

43. Wolsink M.: Entanglement of interests and motives: Assumptions behind the "NIMBY-theory" on facility siting. Urban Stud. 31(6), 851-866 (1994).

44. Wolsink M.: Wind power and the NIMBY-myth: Institutional capacity and the limited significance of public support. Renewable Energy 21(1), 49-64 (2000).

45. Bell D., Gray T., and Haggett C.: The 'social gap' in wind farm siting decisions: Explanations and policy responses. Environ. Polit. 14(4), 460-477 (2005).

46. van der Horst D.: NIMBY or not? Exploring the relevance of location and the politics of voiced opinions in renewable energy siting controversies. Energy Policy 35(5), 2705-2714 (2007).

47. Petrova M.A.: NIMBYism revisited: Public acceptance of wind energy in the United States. Wiley Interdiscip. Rev.: Clim. Change 4(6), 575-601 (2014).

48. Bidwell D.: The role of values in public beliefs and attitudes towards commercial wind energy. Energy Policy 58, 189-199 (2013).

49. Schively C.: Understanding the NIMBY and LULU phenomena: Reassessing our knowledge base and informing future research. J. Plann. Lit. 21(3), 255-266 (2007).

50. Wolsink M.: Invalid theory impedes our understanding: A critique on the persistence of the language of NIMBY. Trans. Inst. Br. Geogr. 31(1), 85-91 (2006).

51. Devine-Wright H. and Devine-Wright P.: Social representations of electricity network technologies: Exploring processes of anchoring and objectification through the use of visual research methods. Br. J. Soc. Psychol. 48(2), 357-373 (2009).

52. Devine-Wright P. and Howes Y.: Disruption to place attachment and the protection of restorative environments: A wind energy case study. J. Environ. Psychol. 30(3), 271-280 (2010).

53. Fischlein M., Wilson E., Stephens J., and Peterson T.: States of transmission: Moving towards large scale wind power. Energy Policy 56, 101-113 (2013).

54. Vajjhala S.P. and Fischbeck P.S.: Quantifying siting difficulty: A case study of U.S. transmission line siting. Energy Policy 35(1), 650-671 (2007).

55. Klass A.B. and Wilson E.J.: Interstate transmission challenges for renewable energy: A federalism mismatch. Vanderbuilt Law Reveiw, 65, 1801-1873 (2012).

56. Devine-Wright P.: Reconsidering Public Attitudes and Public Acceptance of Renewable Energy Technologies: A Critical Review (School of Environment and Development, University of Manchester, Manchester, 2007). Available at: http://www.sed.manchester.ac.uk/research/beyond_nimbyism.

57. Firestone J., Kempton W., and Krueger A.: Public acceptance of offshore wind power projects in the USA. Wind Energy 12(2), 183-202 (2009).

58. Swofford J. and Slattery M.: Public attitudes of wind energy in Texas: Local communities in close proximity to wind farms and their effect on decision-making. Energy Policy 38(5), 2508-2519 (2010).

59. Eltham D.C., Harrison G.P., and Allen S.J.: Change in public attitudes towards a Cornish wind farm: Implications for planning. Energy Policy 36(1), 23-33 (2008).

60. Slattery M.C., Johnson B.L., Swofford J.A., and Pasqualetti M.J.: The predominance of economic development in the support for large-scale wind farms in the US Great Plains. Renewable Sustainable Energy Rev. 16(6), 3690-3701 (2012).
61. Chesto J.: Falmouth Turbine Controversy Could Hinder the Expansion of Wind Energy in the State (Mass Market, 2011). http://blogs.wickedlocal. com/massmarkets/2011/03/08/falmouth-turbine-controversy-couldhinder-the-expansion-of-wind-energy-in-the-state/.

62. Adaramola M.: Solar Energy: Application, Economics, and Public Perception (Apple Academic Press, Oakville, Ontario, Canada, 2014).

63. Kishore P. and Kisiel J.: Exploring high school students' perceptions of solar energy and solar cells. Int. J. Environ. Sci. Educ. 8, 521-534 (2013)

64. Stephens J.C. and Jiusto S.: Assessing innovation in emerging energy technologies: Socio-technical dynamics of carbon capture and storage (CCS) and enhanced geothermal systems (EGS) in the USA. Energy Policy 38, 2020-2031 (2010).

65. Bradbury J., Ray I., Peterson T., Wade S., Wong-Parodi G., and Feldpausch A.: The role of social factors in shaping public perceptions of CCS: Results of multi-state focus group interviews in the US. Energy Procedia 1(1), 4665-4672 (2009).

66. Tokushgie K., Akimoto K., and Tomoda T.: Public perceptions on the acceptance of geological storage of carbon dioxide and information influencing the acceptance. Int. J. Greenhouse Gas Control 1(1), 101-112 (2007).

67. Krohn S. and Damborg S.: On public attitudes towards wind power. Renewable Energy 16(1), 954-960 (1999).

68. Jones C.R. and Eiser J.R.: Identifying predictors of attitudes towards local onshore wind development with reference to an English case study. Energy Policy 37(11), 4604-4614 (2009).

69. Bronfman N.C., Jiminez R.B., Arevalo P.C., and Cifuentes L.A.: Understanding social acceptance of electricity generation sources. Energy Policy 46, 246-252 (2012).

70. Dupuy C. and Torre A.: Local clusters, trust, confidence and proximity. In Clusters and Globalization: The Development of Urban and Regional Economies, Pitelis C., Sugden R. and Wilson J.R. eds.; Edward Elgar Publishing: Northhampton, MA, 2006.

71. Coenen L., Raven R., and Verbong G.: Local niche experimentation in energy transitions: A theoretical and empirical exploration of proximity advantages and disadvantages. Technol. Soc. 32, 295-302 (2010).

72. Krause R.M., Carley S., Warren D.C., Rupp J., and Graham J.D.: Not under my backyard: Geographic proximity and public acceptance of carbon capture and storage (CCS) facilities. In APPAM Annual Meeting, 2012.

73. Shackley S., McLachlan C., and Gough C.: The public perception of carbon dioxide capture and storage in the UK: Results from focus groups and a survey. Clim. Policy 4(4), 377-398 (2005).

74. Moula E., Munjur M., Maula J., Hamdy M., Fang T., Jung N., and Lahdelma R.: Researching social acceptability of renewable energy technologies in Finland. Int. J. Sustainable Built Environ. 2(1), 89-98 (2014).

75. Huijts N.M.A., Molin E.J.E., and Steg L.: Psychological factors influencing sustainable energy technology acceptance: A review-based comprehensive framework. Renewable Sustainable Energy Rev. 16(1), 525-531 (2012).

76. Arvai J.: Risk, perception, Assessment and communication. In Encyclopedia of Environment and Society, Robbins P. ed.; Sage Publications: Thousand Oaks, CA, 2007; pp. 1519-1525.

77. Finucane M.L.: Gender, race, and perceived risk: The 'white male' effect. Health Risk Soc. 2(2), 159-172 (2000).

78. Groth T.M. and Vogt C.: Residents' perceptions of wind turbines: An analysis of two townships in Michigan. Energy Policy 65, 251-260 (2004).

79. Agterbosch S., Glasbergen P., and Vermeulen W.J.V.: Social barriers in wind power implementation in The Netherlands: Perceptions of wind power entrepreneurs and local civil servants of institutional and social conditions in realizing wind power projects. Renewable Sustainable Energy Rev. 11(6), 1025-1055 (2007).

80. Phadke R.: Resisting and reconciling big wind: Middle landscape politics in the New American West. Antipode 43(3), 754-776 (2011).

81. Pasqualetti M.J., Gipe P., and Righter R.W.: Wind Power in View: Energy Landscapes in a Crowded World (Academic Press, Waltham, MA, 2002).

82. Heberlein T.A.: Navigating Environmental Attitudes (Oxford University Press, Oxford, 2012). 
83. Kahan D.: Emotion in risk Regulation: Competing theories. In Emotions and Risky Technologies, Roeser S. ed.; Springer: Netherlands, 2010; pp. 159-175.

84. Sturgis P. and Allum N.: Science in society: Re-evaluating the deficit model of public attitudes. Publ. Understand. Sci. 13(1), 55-74 (2004).

85. Meadowcroft J.: Participation and sustainable development: Modes of citizen, community and organizational involvement. In Governance for Sustainable Development: The Challenge of Adapting Form to Function, Lafferty W.M. ed.; Edward Elgar: Cheltenham, UK, 2004; pp. 162-190.

86. Peterson T.R. and Feldpausch-Parker A.: Environmental conflict communication. In The SAGE Handbook of Conflict Communication: Integrating Theory, Research, and Practice, Oetzel J.G. and Ting-Toomey S. eds.; Sage: Thousand Oaks, CA, 2013; pp. 513-537.

87. Arnstein S.R.: A ladder of citizen participation. J. Am. Plann. Assoc. 35(4), 216-224 (1969).

88. Cox Callister D.: Land community participation: A new "Public" participation model. Environ. Commun. 7(4), 435-455 (2013).

89. Salzman J. and Thompson B.H.: Environmental Law and Policy (Foundation Press, New York, 2010).

90. Hunter D. and Zaelke D.: International Environmental Law and Policy (Foundation Press, New York, 2010).

91. Barnett J., Burningham K., Walker G., and Cass N.: Imagined publics and engagement around renewable energy technologies in the UK. Publ. Understand. Sci. 21(1), 36-50 (2012).

92. Barry J., Ellis G., and Robinson C.: Cool rationalities and hot air: A rhetorical approach to understanding debates on renewable energy. Global Environ. Polit. 8(2), 67-98 (2008).

93. Hall N., Ashworth P., and Devine-Wright P.: Societal acceptance of wind farms: Analysis of four common themes across Australian case studies. Energy Policy 58, 200-208 (2013).

94. Wolsink M.: Wind power implementation: The nature of public attitudes: Equity and fairness instead of 'backyard motives'. Renewable Sustainable Energy Rev. 11(6), 1188-1207 (2007).

95. Firestone J. and Kempton W.: Public opinion about large offshore wind power: Underlying factors. Energy Policy 35, 1584-1598 (2007).

96. Breeze R.: Legitimation in corporate discourse: Oil corporations after deepwater horizon. Discourse Soc. 23(1), 3-18 (2012).

97. Olaniran B.A. and Williams D.E.: Applying anticipatory and relational perspectives to the Nigerian delta region oil crisis. Publ. Relat. Rev. 34(1), 57-59 (2008).

98. Williams D.E. and Olaniran B.A.: Exxon's decision-making flaws: The hypervigilant response to the Valdez grounding. Publ. Relat. Rev. 20(1), 5-18 (1994).

99. Williams D.E. and Treadaway G.: Exxon and the Valdez accident: A failure in crisis communication. Commun. Stud. 43(1), 56-64 (1992).

100. Cotton A.J., Veil S.R., and Iannarino N.T.: Contaminated communication: TEPCO and organizational renewal at the fukushima daiichi nuclear power plant. Commun. Stud. 66, 27-44 (2015).

101. Miller B.M. and Lellis J.C.: Response to marketplace advocacy messages by sponsor and topic within the energy industry: Should corporations or industry trade groups do the talking? J. Appl. Commun. Res. 43(1), 66-90 (2015).

102. Miller B.M.: Community stakeholders and marketplace advocacy: A model of advocacy, agenda building, and industry approval. J. Publ. Relat. Res. 22(1), 85-112 (2010).

103. Chewning L.V.: Multiple voices and multiple media: Co-constructing BP's crisis response. Publ. Relat. Rev. 41, 72-79 (2015). doi: 10.1016/j.pubrev. 2014.10.012(1)

104. Webster F. ed.: Culture and Politics in the Information Age: A New Politics? (Routledge, London, 2001).

105. Utz S., Schultz F., and Glocka S.: Crisis communication online: How medium, crisis type and emotions affected public reactions in the Fukushima Daiichi nuclear disaster. Publ. Relat. Rev. 39(1), 40-46 (2013).

106. Wakefield S.E.L. and Elliott S.J.: Constructing the news: The role of local newspapers in environmental risk communication. Prof. Geogr. 55(2), 216-226 (2003).
107. Graber D.A.: Mass Media and American Politics (CQ Press, Washington, DC, 1997).

108. Hansen A.: The media and the social construction of the environment. Media Cult. Soc. 13, 443-458 (1991).

109. McCombs M.: The agenda-setting role of the mass media in the shaping of public opinion. In Mass Media Economics 2002 Conference, London School of Economics: London, UK, 2002.

110. Gamson W.A. and Modigliani A.: Media discourse and public opinion on nuclear power: A Constructionist approach. Am. J. Sociol. 95(1), 1-37 (1989).

111. Feldpausch-Parker A.M. and Peterson T.R.: Communicating the science behind carbon sequestration: A case study of US Department of Energy and Regional Partnership websites. Environ. Commun. 7(3), 1-20 (2014).

112. Feldpausch-Parker A.M., Chaudhry R., Stephens J., Fischlein M., Hall D., Melnick L., Peterson T., Ragland C., and Wilson E.J.: Spreading the news on carbon capture and storage: A state-level comparison of US media. Environ. Commun. 7(3), 336-354 (2013).

113. McCombs M.E.: Setting the Agenda: The Mass Media and Public Opinion (Polity Press, Cambridge, UK, 2004).

114. Feldpausch-Parker A.M., Chaudry R., Stephens J.C., Fischlein M., Hall D.M., Melnick L.L., Peterson T.R., Ragland C.J., and Wilson E.J.: A comparative state-level analysis of carbon capture and storage (CCS) discourse among U.S. energy stakeholders and the public. Energy Procedia 4(4), 6368-6375 (2011).

115. Culbertson H.M. and Stempel G.H.: "Media malaise" : Explaining personal optimism and societal pessimism about health care. J. Commun. 35, 180-190 (1985).

116. Dunwoody S. and Neuwirth K.: Coming to terms with the impact of communication on scientific and technological risk judgments. In Risky Business: Communicating Issues of Science, Risk and Public Policy, Wilkins L. and Patterson P. eds.; Greenwood Press: Westport, CT, 1991; pp. 11-30.

117. Gregory R.: Improving risk communications: Questions of content and intent. In Prospects and Problems in Risk Communication, Leiss W. ed.; University of Waterloo Press: Waterloo, 1989; pp. 71-80.

118. Murray D., Schwartz J., and Lichter S.R.: It Ain't Necessarily So: How Media Make and Unmake the Scientific Picture of Reality (Rowman \& Littlefield Publishers, Inc., Lanham, MD, 2001).

119. Singer E.T. and Endreny P.M.: Reporting hazards: Their benefits and costs. J. Commun. 37(3), 10-26 (1987).

120. Nelson T., Oxley Z., and Clawson R.: Toward a psychology of framing effects. Polit. Behav. 19(3), 221-246 (1997).

121. Crawley C.E.: Localized debates of agricultural biotechnology in community newspapers-A quantitative content analysis of media frames and sources. Sci. Commun. 28(3), 314-346 (2007).

122. Schirrmeister M.: Controversial futures-Discourse analysis on utilizing the "fracking" technology in Germany. Eur. J. Futures Res. 2, 38 (2014).

123. Stephens J.C., Rand G.M., and Melnick L.L.: Wind energy in US Media: A comparative state-level analysis of a critical climate change mitigation technology. Environ. Commun.: J. Nat. Cult. 3(2), 168-190 (2009).

124. Corbett J.B. and Durfee J.L.: Testing public (un)certainty of science: Media representations of global warming. Sci. Commun. 26(2), 129-151 (2004).

125. Boyd A., Einsiedel E., Liu Y., Meadowcroft J., Peterson T., Pollak M., Stephens J., and Wilson E.: Controversy in technology innovation: Contrasting media and expert risk perception of the alleged leakage at the Weyburn carbon dioxide storage demonstration project. Int. J. Greenhouse Gas Controls 14, 259-269 (2013).

126. Langheim R., Skubel M., Chen X., Maxwell W., Peterson T.R., Wilson E.J., and Stephens J.C.: Smart grid coverage in U.S. newspapers: Characterizing public conversations. Electr. J. 27(5), 77-87 (2014).

127. Fischlein M., Peterson T.R., Stephens J.C., and Wilson E.J.: Which way does the wind blow? Analyzing the sub-national context for renewable energy deployment in the United States. Environ. Governance 24(3), 169-187 (2014).

128. Stephens J., Peterson T., and Wilson E.: Socio-political evaluation of energy deployment (SPEED): A framework applied to smart grid UCLA Law Review 61, 1930-1961 (2014). 
129. Davies S.R. and Selin C.: Energy futures: Five dilemmas of the practice of anticipatory governance. Environ. Commun. 6(1), 119-136 (2012).

130. Endres D., Sprain L., and Peterson T.R.: Social Movement to Address Climate Change: Local Steps for Global Action (Cambria Press, Amherst, NY, 2009).

131. Kinsella W.J., Kelly A.R., and Kittle Autry M.: Risk, regulation, and rhetorical boundaries: Claims and challenges surrounding a purported nuclear renaissance. Commun. Monogr. 80(3), 278-301 (2013).

132. Klassen J.A. and Feldpausch-Parker A.M.: Oiling the gears of public participation: The value of organisations in establishing trinity of voice for communities impacted by the oil and gas industry. Local Environ. 16(9), 903-915 (2011).

133. Sterman J.D.: Communicating climate change risks in a skeptical world. Clim. Change 108, 811-826 (2011).

134. Fischhoff B.: The nuclear energy industry's communication problem. Bull. At. Sci. (2009). http://thebulletin.org/nuclear-energy-industryscommunication-problem.

135. Zoellner J., Schweizer-Ries P., and Wemheuer C.: Public acceptance of renewable energies: Results from case studies in Germany. Energy Policy 36(11), 4136-4141 (2008).

136. Kaldellis J.K. and Kavadias K.A.: Evaluation of Greek wind parks visual impact. "The public attitude". Fresenius Environ. Bull. 13(5), 413-423 (2004).

137. Kaldellis J.K.: Social attitude towards wind energy applications in Greece. Energy Policy 33(5), 595-602 (2005).

138. Maillé M-È. and Saint-Charles J.: Fuelling an environmental conflict through information diffusion strategies. Environ. Commun. 8(3), 305-325 (2014).

139. Fenton P., Gustafsson S., Ivner J., and Palm J.: Stakeholder participation in municipal energy and climate planning-Experiences from Sweden. Local Environ. 1-18 (2014).

140. Munday M., Bristow G., and Cowell R.: Wind farms in rural areas: How far do community benefits from wind farms represent a local economic development opportunity? J. Rural. Stud. 27(1), 1-12 (2011).

141. Warren C.R. and McFadyen M.: Does community ownership affect public attitudes to wind energy? A case study from south-west Scotland. Energy Policy 27, 204-213 (2010).

142. Musall F.D. and Kuik O.: Local acceptance of renewable energy-A case study from southeast Germany. Energy Policy 39(6), 3252-3260 (2011).

143. Dinica V.: Initiating a sustained diffusion of wind power: The role of public-private partnerships in Spain. Energy Policy 36(9), 3562-3571 (2008).

144. Toke D., Breukers S., and Wolsink M.: Wind power deployment outcomes: How can we account for the differences? Renewable Sustainable Energy Rev. 12(4), 1129-1147 (2008).

145. Fontaine G.: The effects of governance modes on the energy matrix of Andean countries. Energy Policy 39(5), 2888-2898 (2011).

146. EcoGrid E.U.: Eco Grid EU: From Design to Implementation, European Union's Seventh Framework Programme for Research (FP7), Zurich, Switzerland, 2013.

147. Kumagai J.: The smartest, greenest grid: What the little Danish Island of Bornholm about the future of energy. IEEE Spectrum 50(5), 42-47 (2013).

148. Leiserowitz A.A.: American risk perceptions: Is climate change dangerous? Risk Anal. 25(6), 1433-1442 (2005).
149. Boykoff M.T. and Boykoff J.M.: Climate change and journalistic norms: A case-study of US mass-media coverage. Geoforum 38(6), 1190-1204 (2007).

150. Fletcher A.L.: Clearing the air: The contribution of frame analysis to understanding climate policy in the United States. Environ. Polit. 18(5), 800-816 (2009).

151. Wilson E.J. and Stephens J.C.: Wind in a carbon-managed world: States, resources, policy and discourse. Environ. Sci. Technol. 43(24), 9063-9070 (2009).

152. Feldpausch-Parker A.M., O’Byrne M., Endres D., and Peterson T.R.: The Adventures of Carbon Bond: Using a melodramatic game to explain CCS as a mitigation strategy for climate change. Greenhouse Gases: Sci. Technol. 3(1), 21-29 (2013).

153. Perreault T. and Valdivia G.: Hydrocarbons, popular protest and national imaginaries: Ecuador and Bolivia in comparative context. Geoforum 41(5), 689-699 (2010).

154. Fischlein M., Larson J., Hall D.M., Chaudhry R., Peterson T.R., Stephens J.C., and Wilson E.J.: Policy stakeholders and deployment of wind power in the sub-national context: A comparison of four U.S. states. Energy Policy 38, 4429-4439 (2010).

155. Galbraith K. and Price A.: The Great Texas Wind Rush (University of Texas Press, Austin, Texas, 2013).

156. Lasher W.P.: 2008. The development of competitive renewable energy zones in Texas, Transmission and Distribution Conference and Exposition, 2008. T\&D. IEEE/PES. IEEE, pp. 1-4. Chicago, IL April 21-24. http://ieeexplore.ieee.org/stamp/stamp.jsp?tp=\&arnumber $=4517254$.

157. Esposito M.J., Russell C., and Levy H.L.: School of Law Wildcatting for Wind the Texas Experience from Turbine to Market. University of Texas School of Law, Continuing Legal Education in cooperation with Kestrel Filmworks, 2007.

158. Slattery M.C., Lantz E., and Johnson B.L.: State and local economic impacts from wind energy projects: Texas case study. Energy Policy 39(12), 7930-7940 (2011).

159. Kimmell K. and Stalenhoef D.S.: Cape wind offshore wind energy project: A case study of the difficult transition to renewable energy. Golden Gate U. Envtl. L.J. 5, 197 (2011).

160. Firestone J., Kempton W., Lilley M.B., and Samoteskul K.: Public acceptance of offshore wind power across regions and through time. J. Environ. Plann. Manage. 55(10), 1369-1386 (2012).

161. Firestone J., Kempton W., Lilley M.B., and Samoteskul K.: Public acceptance of offshore wind power: Does perceived fairness of process matter? J. Environ. Plann. Manage. 55(10), 1387-1402 (2012).

162. Pasqualetti M.J.: Opposing wind energy landscapes: A search for common cause. Ann. Assoc. Am. Geogr. 101(4), 907-917 (2011).

163. U.S. Census Bureau: Income: State Median Income (U.S. Census Bureau, Washington, DC, 2015).

164. Bolinger M.: Community Wind Power Ownership Schemes in Europe and Their Relevance to the United States, Environmental Energy Technology Division ed.; Lawrence Berkeley National Laboratory: Berkeley, CA, 2001.

165. Arent A.: Power. Federal Theatre Project, 1937. http://newdeal.feri.org/ power/

166. Jacobson M.Z., Howarth R.W., Delucchi M.A., Scobie S.R., Barth J.M., Dvorak M.J., Klevze M., Katkhuda H., Miranda B., Chowdhury N.A., Jones R., Plano L., and Ingraffea A.R.: Examining the feasibility of converting New York State's all-purpose energy infrastructure to one using wind, water, and sunlight. Energy Policy 57, 585-601 (2013). 